\title{
Pengembangan Modul Larutan Elektrolit dan Non Elektrolit Berbasis Pendekatan Saintifik dengan Pertanyaan Probing Prompting untuk Kelas X SMA/MA
}

\author{
D Yuliantika ${ }^{1}$ and Ellizar ${ }^{1^{*}}$ \\ ${ }^{1}$ Pendidikan Kimia, Universitas Negeri Padang, Jl. Prof. Dr. Hamka Air Tawar Barat, \\ Padang Utara, Sumatera Barat 25171, Indonesia \\ *non_jalius@yahoo.com
}

\begin{abstract}
Abstrak. Curriculum 2013 equires learning to be able to improve students' activeness and thinking skills. One effort that can be done is by giving probing prompting questions. This study aims to develop module of electrolyte and non-electrolyte solutions based on a scientific approach with each step containing probing prompting questions. The type of research used is $\mathrm{R} \& \mathrm{D}$ (Research and Development) through the stages of 4-D development model. The research phase carried out include 1) define phase, 2) design stage, 3) develop stage and disseminate stage. However, the research is limited to develop stage. The module developed was tested for validity and practicality through the provision of questionnaires and processed using Cohen's kappa formula. Based on the results of the study of validity tests on 5 validators ( 2 lecturers and 3 teachers), the kappa moment was 0.86 with very high validity. Meanwhile, based on the practicality test conducted at SMAN $12 \times 11$ Enam Lingkung by 3 teachers and 29 students, each kappa moment was 0.89 and 0.86 . This shows that the module of electrolyte and non-electrolyte solutions based on the scientific approach using probing prompting for grade X SMA/MA has been valid and practical to be used in the learning process.
\end{abstract}

\section{Pendahuluan}

Pengimplementasian Kurikulum 2013 dalam pembelajaran dengan pendekatan saintifik diharapkan dapat melatih siswa berpikir analitis bukan mekanistis [1]. Pendekatan saintifik merupakan proses pembelajaran yang dirancang sedemikian rupa agar peserta didik secara aktif mengonstruk konsep, hukum atau prinsip tahapan-tahapan ilmiah [2]. Terdapat 5 tahapan ilmiah dalam pendekatan saintifik yaitu mengamati, menanya, menalar, mengasosiasi dan mengomunikasikan [3].

Kurikulum 2013 menuntut pembelajaran untuk meningkatkan keaktifan dan keterampilan berpikir siswa. Untuk memenuhi tuntutan tersebut perlu dilakukan usaha melalui pemberian pertanyaan dalam proses belajar sehingga keterampilan berpikir siswa dapat ditingkatkan. Hal tersebut dapat terjadi dimana dengan dilontarkannya beberapa pertanyaan, siswa secara bertahap menjadi aktif dan banyak berpartisipasi dalam bertanya atau menjawab pertanyaan [4].

Salah satu teknik bertanya yang dapat meningkatkan keaktifan dan keterampilan berpikir siswa adalah dengan pertanyaan probing prompting. Probing adalah pertanyaan yang bersifat menggali dan prompting adalah pertanyaan yang bersifat membimbing/menuntun [4]. Sedangkan pembelajaran probing prompting dilakukan dimana guru menyajikan serangkaian pertanyaan yang sifatnya menggali dan menuntun sehingga terjadi proses berpikir siswa terhadap pengetahuan baru yang sedang dipelajari [5].

Kimia merupakan salah satu mata pelajaran yang tidak mudah dipahami oleh semua siswa karena bersifat abstrak dan memerlukan pemahaman konseptual [6]. Materi larutan elektrolit dan non elektrolit merupakan salah satu materi bidang studi kimia yang bersifat abstrak sehingga menyebabkan peserta didik sulit memahaminya. Sebagai contoh interaksi ion-ion di dalam larutan yang menghantarkan arus 
listrik tidak dapat diamati langsung, namun dapat dikenali dari gejala-gejala yang terjadi. Konsep seperti ini akan lebih mudah dipelajari siswa dengan memberikan ilustrasi berupa gambar atau model yang berhubungan dengan materi.

Berdasarkan hasil analisis angket respon siswa kelas XI di SMAN 5 Padang, SMAN 12 Padang serta SMAN 12 2x11 Enam Lingkung, diketahui umumnya siswa masih kesulitan dalam memahami materi larutan elektrolit dan non elektrolit. Hal ini terlihat dari data hasil angket di SMAN 12 x11 Enam Lingkung dan SMAN 12 Padang yang menunjukkan 70\% siswa masih sulit dalam mengelompokkan larutan ke dalam elektrolit kuat, lemah dan non elektrolit. Selain itu di SMAN 5 Padang diketahui 70\% siswa sulit dalam menentukan senyawa yang bersifat elektrolit.

Ditinjau dari keterangan guru mengenai bahan ajar yang digunakan umumnya belum bervariasi dan masih berupa buku teks serta LKPD. Bahan ajar yang tersedia diketahui belum menarik dan belum mampu menjadikan siswa untuk memahami materi secara mandiri. Namun sebaliknya, dengan tersedianya bahan ajar yang bervariasi menjadi lebih menarik dan siswa memiliki lebih banyak kesempatan belajar mandiri [7].

Diketahui dari hasil wawancara dengan guru, meskipun telah menerapkan Kurikulum 2013 guru masih terkendala dalam mengupayakan siswa aktif selama proses pembelajaran, serta siswa belum terlatih menerapkan tahapan pendekatan saintifik. Hal ini dapat menjadi salah satu faktor penyebab pembelajaran belum dapat meningkatkan keterampilan berpikir kritis, sehingga siswa masih kesulitan dalam menemukan konsep secara mandiri.

Berdasarkan permasalahan tersebut, diperlukan suatu bahan ajar yang dapat menuntun siswa berpikir aktif dalam proses pembelajaran. Sikap siswa dalam pembelajaran menggunakan modul tercermin dari tingkat kesenangannya ketika belajar atau membaca teks yang bergambar. Disamping itu, bagan dan gambar yang berwarna pada modul dapat meningkatkan retensi karena otak lebih aktif, sehingga dapat meningkatkan rasa senang siswa dan termotivasi untuk belajar [8]. Selain itu, pembelajaran dengan probing-prompting dapat menggali kemampuan berpikir siswa [9]. Namun pada sisi lain suatu pertanyaan bisa jadi positif atau negatif [10]. Oleh sebab itu, guru perlu memikirkan dan menyusunnya dengan baik. Salah satu upaya yang dapat dilakukan adalah dengan menyajikan pertanyaan probing dan prompting ke dalam bahan ajar berupa modul. Setiap tahapan pendekatan saintifik dalam modul selanjutnya dibantu dengan menggunakan pertanyaan probing prompting, sehingga dengan ini modul berfungsi untuk membantu guru menggunakan teknik bertanya sekaligus akan meningkatkan keaktifan dan keterampilan berpikir siswa.

Berdasarkan uraian permasalahan diatas, perlu dilakukan penelitian untuk mengembangkan bahan ajar alternatif berupa modul dengan judul "Pengembangan Modul Larutan Elektrolit dan Non Elektrolit Berbasis Pendekatan Saintifik dengan Pertanyaan Probing Prompting untuk Kelas X SMA/MA".

\section{Metode Penelitian}

Jenis penelitian yang digunakan adalah metode penelitian dan pengembangan atau Research and Development (R\&D) dengan model pengembangan 4-D. Model 4-D terdiri dari empat tahapan penelitian yaitu tahap define, design, develop dan disseminate [11]. Namun penelitian ini dibatasi sampai pada tahap develop saja. Subjek pada penelitian ini adalah 2 orang dosen jurusan kimia FMIPA UNP, 3 orang guru kimia SMAN $12 x 11$ Enam Lingkung dan 29 orang siswa SMAN 1 2x11 Enam Lingkung. Adapun objek yang diteliti adalah bahan ajar berupa modul larutan elektrolit dan non elektrolit berbasis pendekatan saintifik dengan pertanyaan probing prompting untuk kelas X SMA/MA.

Tahap awal dalam penelitian ini adalah tahap define (pendefinisian) dengan tujuan menetapkan dan mendefinisikan syarat-syarat pembelajaran. Lima kegiatan pada tahap define diantaranya 1) analisis ujung depan, yaitu menganalisis pembelajaran yang diharapkan kurikulum dengan kenyataan di lapangan. Dalam tahap ini, dilakukan wawancara guru kimia dan pemberian angket pada siswa SMA Kelas XI yang telah mempelajari materi larutan elektrolit dan non elektrolit; 2) analisis siswa, untuk menelaah karakteristik siswa mengenai kemampuan akademik, psikomotor dan motivasi belajar. Dalam tahap ini dilakukan wawancara guru dan pemberian angket respon siswa; 3) analisis tugas, bertujuan untuk mengidentifikasi kemampuan yang harus dikuasai siswa dalam satuan pembelajaran dengan cara menganalisis Kompetensi Dasar 3.8 dan 4.8 sehingga diperoleh Indikator Pencapaian Kompetensi; 4) analisis konsep, tahap ini bertujuan untuk mengetahui konsep-konsep utama yang dipelajari pada materi 
larutan elektrolit dan non elektrolit, mengaitkan antarkonsep serta disusun secara sistematis membentuk peta konsep; dan 5) analisis tujuan pembelajaran, merupakan tahap pengubahan hasil analisis tugas dan analisis konsep menjadi suatu rumusan yang menggambarkan hasil belajar yang diharapkan.

Pada tahap design, dilakukan perancangan bahan ajar pada materi larutan elektrolit dan non elektrolit sesuai dengan yang telah dirumuskan pada tahap define. Terdapat tiga langkah kegiatan yang dilakukan yaitu, 1) pemilihan bahan ajar, dipilih yang relevan dengan materi pembelajaran dan kebutuhan di lapangan; 2) pemilihan format, meliputi pemilihan pendekatan yang digunakan untuk merancang isi pembelajaran serta format acuan penyusunan bahan ajar yang sesuai dengan Depdiknas tahun 2008; 3) rancangan awal, dihasilkan rancangan bahan ajar berupa modul yang disusun sesuai pemilihan format dengan memuat komponen cover, petunjuk belajar, kompetensi yang dicapa, peta konsep, lembar kegiatan, lembar kerja, evaluasi, kunci jawaban dan daftar pustaka [7].

Selanjutnya tahap develop dilakukan uji validasi, revisi dan uji praktikalitas. Kegiatan pertama, uji validasi terhadap rancangan awal modul yang dilakukan oleh validator ( 2 dosen dan 3 guru kimia) untuk mendapatkan saran dan masukan serta menilai kevalidan modul. Kedua, dilakukan revisi terhadap modul sesuai saran-saran yang diberikan sampai modul dinyatakan valid oleh validator. Ketiga, dilakukan uji praktikalitas modul oleh 3 orang guru dan 29 orang siswa untuk menilai kepraktisan modul yang dikembangkan. Selanjutnya juga dilakukan revisi terhadap modul sesuai saran dari guru maupun siswa.

Jenis data yang diperoleh pada pengembangan modul larutan elektrolit dan non elektrolit berbasis pendekatan saintifik dengan pertanyaan probing prompting untuk kelas X SMA/MA adalah data primer, dengan instrumen penelitian yang digunakan diantaranya lembar wawancara guru, lembar angket respon siswa, lembar angket validitas dan lembar angket praktikalitas. Data yang diperoleh dari pemberian angket pada uji validitas dan praktikalitas diolah menggunakan formula Kappa Cohen untuk memperoleh momen kappa dengan rumus dan kategori keputusan momen kappa sebagai berikut

Keterangan: $k=$ momen kappa

$$
\text { moment kappa }(k)=\frac{P-P e}{1-P e}
$$

$$
\begin{aligned}
& P=\text { proporsi yang terealisasi } \\
& P e=\text { proporsi yang tidak terealisasi }
\end{aligned}
$$

Tabel 1. Kategori Keputusan Berdasarkan Momen Kappa (k)

\begin{tabular}{c|c} 
Interval & Kategori kevalidan \\
\hline $0,81-1,00$ & Sangat tinggi \\
\hline $0,61-0,80$ & Tinggi \\
\hline $0,41-0,60$ & Sedang \\
\hline $0,21-0,40$ & Rendah \\
\hline $0,01-0,20$ & Sangat rendah \\
\hline 0,00 & Tidak valid
\end{tabular}

\section{Hasil dan Pembahasan}

\subsection{Tahap difine}

3.1.1. Analisis ujung depan. Diperoleh informasi diantaranya, 1) Siswa masih mengalami kesulitan dalam memahami materi larutan elektrolit dan non elektrolit; 2) Bahan ajar yang digunakan disekolah belum bervariasi, masih berupa buku teks dan LKPD; 3) Bahan ajar yang tersedia belum mampu menunjang siswa memahami konsep secara mandiri serta belum menarik; 3) Guru masih terkendala dalam menjadikan siswa aktif selama pembelajaran; 4) Siswa masih belum terampil menerapkan tahapan pendekatan saintifik dan; 5) Belum tersedianya bahan ajar berupa modul.

3.1.2. Analisis siswa. Diketahui bahwa siswa lebih menyukai pembelajaran dengan menggunakan bahan ajar yang menarik, memuat gambar yang berwarna dan kalimat yang jelas, sehingga pembelajaran 
tidak membosankan dan siswa menjadi aktif, serta mampu memahami konsep secara mandiri.

3.1.3. Analisis tugas. Berdasarkan analisis Kompetensi Dasar 3.8 dan 4.8 diperoleh Indikator Pencapaian Kompetensi (IPK) yaitu, 1) menyimpulkan pengertian larutan elektrolit dan non elektrolit; 2) menganalisis sifat larutan elektrolit dan non elektrolit; 3) mengelompokkan larutan ke dalam elektrolit kuat, elektrolit lemah, dan non elektrolit; 4) menganalisis senyawa yang bersifat elektrolit; 5) menganalisis penyebab kemampuan larutan elektrolit dapat menghantarkan arus listrik; 6) menentukan derajat ionisasi suatu larutan dari data yang diketahui dan; 7) mengidentifikasi peran larutan elektrolit dalam tubuh manusia.

3.1.4. Analisis konsep. Diperoleh tabel analisis konsep yang memuat konsep-konsep utama pada materi larutan elektrolit dan non elektrolit serta tersusun sistematis menjadi sebuah peta konsep.

3.1.5. Analisis tujuan pembelajaran. Tujuan pembelajaran yang dirumuskan yaitu melalui modul pembelajaran berbasis pendekatan saintifik dengan pertanyaan probing prompting, dengan menggali informasi dari berbagai sumber belajar, penyelidikan sederhana dan mengolah informasi, diharapkan siswa terlibat aktif selama proses belajar mengajar berlangsung, memiliki sikap ingin tahu, teliti dalam melakukan pengamatan dan bertanggungjawab dalam menyampaikan pendapat, menjawab pertanyaan, memberi saran dan kritik, serta dapat menganalisis sifat larutan berdasarkan daya hantar listriknya serta dapat membedakan daya hantar listrik berbagai larutan melalui perancangan dan pelaksanaan percobaan.

\subsection{Tahap design}

Dihasilkan rancangan awal bahan ajar berupa modul pada materi larutan elektrolit dan non elektrolit berbasiskan pendekatan saintifik dengan pertanyaan probing prompting yang terdiri dari cover, petunjuk belajar, kompetensi yang dicapai, peta konsep, lembar kegiatan, lembar kerja, evaluasi, kunci jawaban dan daftar pustaka. Setiap lembar kegiatan dikembangkan dengan tahapan pendekatan saintifik yang terdiri dari tahap mengamati, menanya, menalar, mengasosiasi dan mengomunikasikan. Pada masingmasing tahapan terdapat pertanyaan yang sifatnya menggali (probing) dan menuntun (prompting) yang diawali dengan penyajian gambar/data. Berdasarkan gambar/data tersebut, guru memberikan pertanyaan probing prompting dan dijawab langsung oleh siswa sehingga tercipta pembelajaran yang aktif. Pengembangan modul dirancang menggunakan Microsoft Word 2013 dan CorelDraw X7 serta didukung dengan ChemDraw 3D. Adapun bentuk rancangan modul dapat dilihat pada Gambar 1.

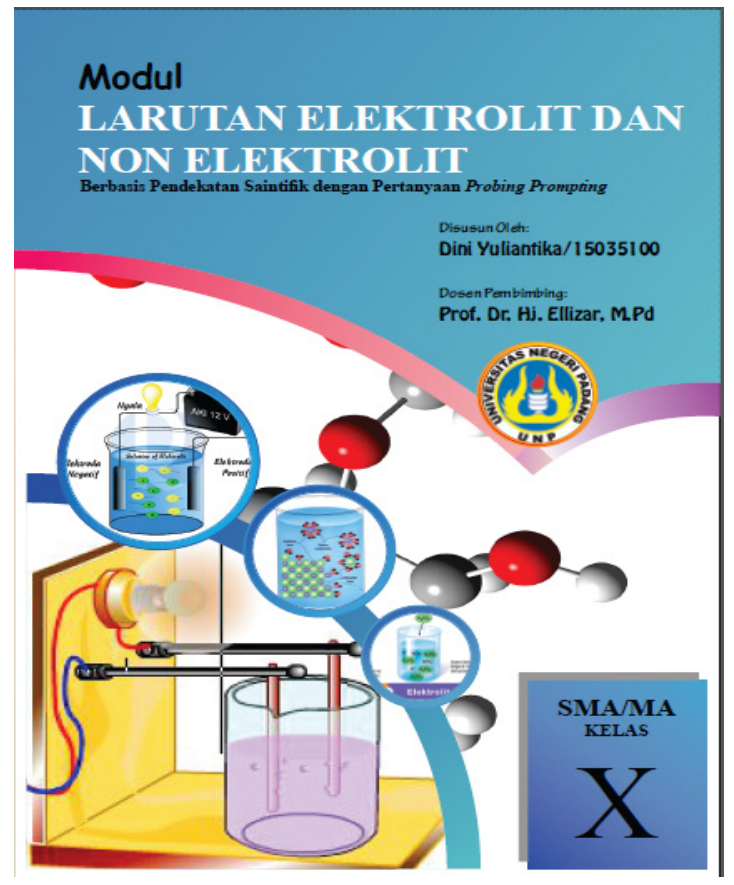

(a)

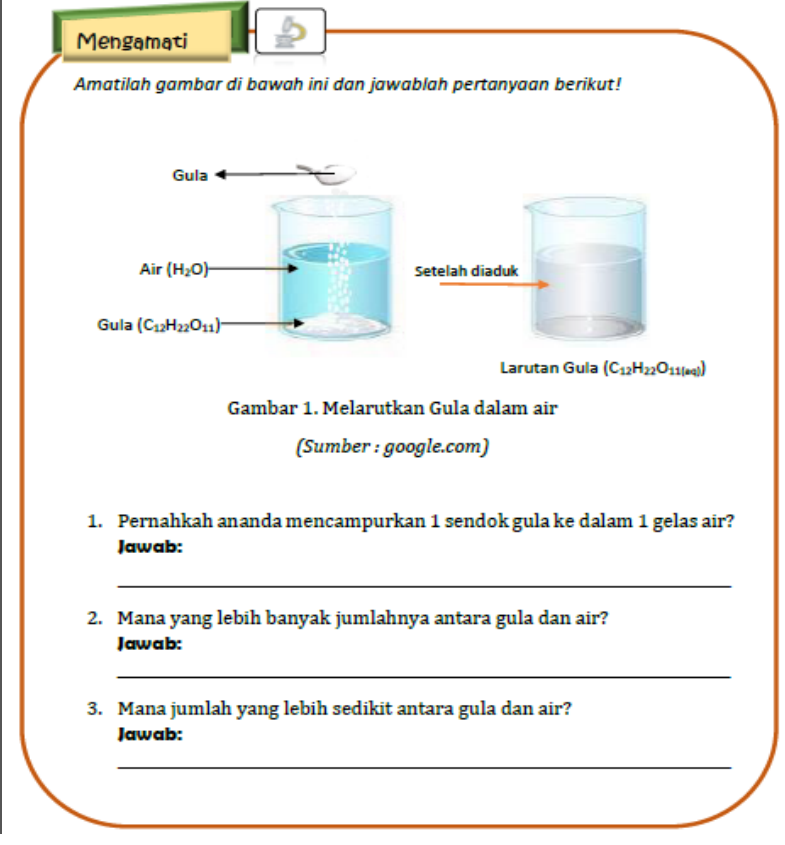

(b)

Gambar 1. Bentuk Rancangan Modul yang Dikembangkan. (a) Cover; (b) Lembar Kegiatan 


\subsection{Tahap develop}

3.3.1. Uji Validitas. Uji validitas dapat dilakukan menggunakan pendapat para ahli (judgment expert) dengan jumlah minimal 3 orang [12]. Semakin banyak validator maka akan semakin bagus hasil yang didapat, dikarenakan akan semakin banyak masukan dan saran dari para ahli sehingga kevalidan modul jadi lebih baik. Penilaian kevalidan modul meliputi empat komponen yaitu komponen isi, komponen kebahasaan, komponen penyajian, dan komponen kegrafikan. Rata-rata perolehan momen kappa masing-masing komponen oleh kelima validator dapat dilihat pada Grafik 1.

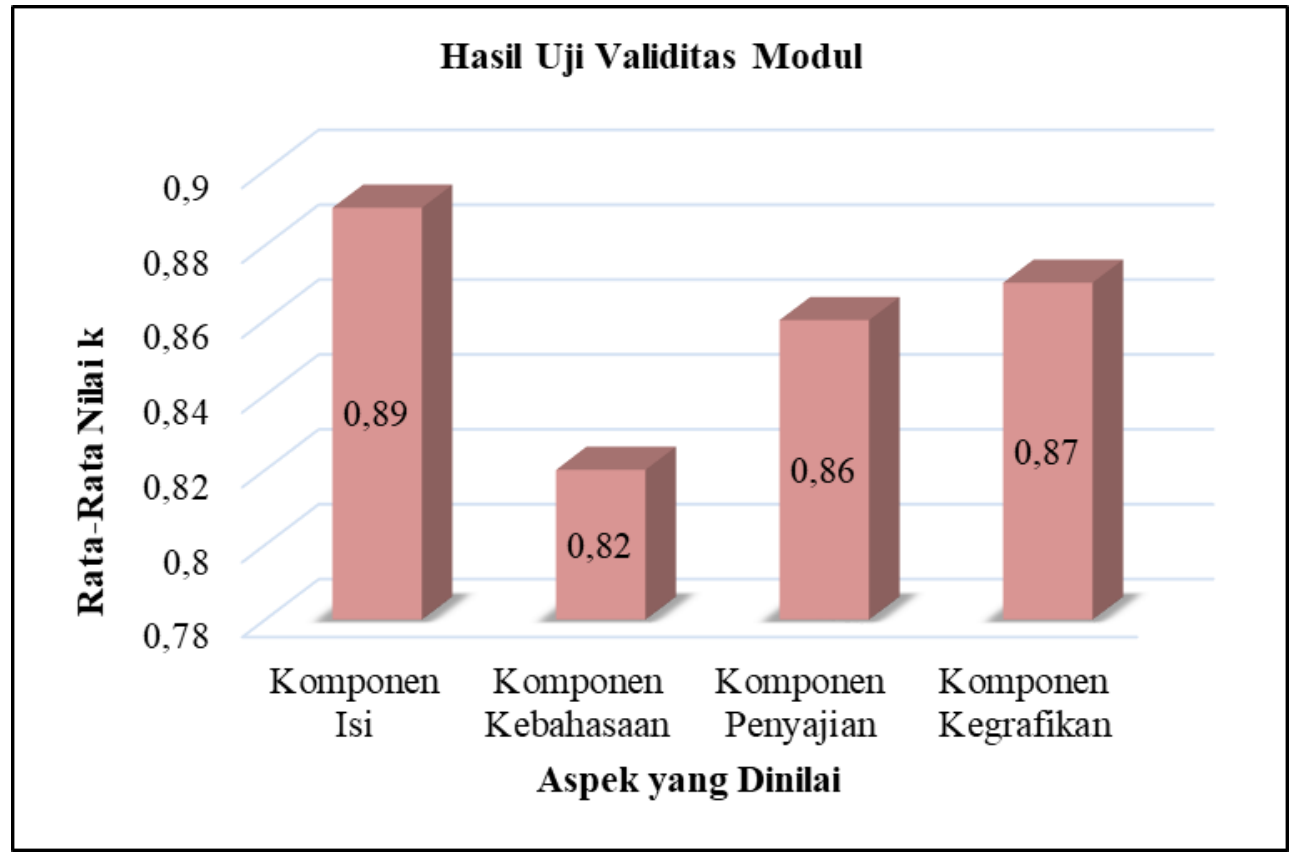

Grafik 1. Nilai momen kappa masing-masing komponen penilaian validitas modul

Berdasarkan grafik diatas terlihat bahwa rata-rata momen kappa masing-masing komponen penilaian berada pada interval 0,81-1,00 dengan kategori kevalidan sangat tinggi. Nilai rata-rata momen kappa pada komponen isi yaitu 0,89 . Nilai tersebut menginformasikan bahwa modul yang dikembangkan telah sesuai dengan tuntutan Kompetensi Dasar Kurikulum 2013 yaitu pada KD 3.8 dan 4.8, dimana modul yang baik harus menggambarkan KD yang akan dicapai siswa [7]. Selain itu, modul yang dihasilkan telah sesuai dengan kemampuan siswa SMA/MA, dimana soal-soal baik pada lembar kerja maupun evaluasi berhubungan dengan materi yang dipelajari. Tidak hanya itu, substansi materi pada modul telah sesuai dengan karakteristik materi larutan elektrolit dan non elektrolit. Begitu juga dengan gambar yang disediakan pada modul, disamping dapat menambah daya tarik siswa [7], juga dapat memberikan informasi mengenai materi sehingga akan menambah wawasan pengetahuan siswa.

Modul dilihat dari komponen kebahasaan memiliki rata-rata momen kappa sebesar 0,82. Hal ini menunjukkan bahwa modul telah menggunakan bahasa yang mudah dipahami, yaitu sesuai dengan kaidah tata Bahasa Indonesia yang baik dan benar, sehingga informasi yang disajikan dalam modul pun jelas. Dimana, modul hendaknya menggunakan kalimat sederhana sehingga menjadi kalimat yang komunikatif dan menarik minat siswa [13]. Hal ini juga didukung dengan penggunaan bentuk dan ukuran huruf yang jelas serta simbol/lambang yang konsisten sehingga nyaman untuk dibaca oleh pengguna.

Nilai rata-rata momen kappa untuk komponen penyajian adalah 0,86 dengan kevalidan sangat tinggi. Hal ini membuktikan bahwa modul telah disusun secara sistematis mengikuti pedoman penyusunan modul dalam Depdiknas. Selain itu modul yang dikembangkan telah sesuai dengan indikator dan tujuan pembelajaran, dimana materi disajikan berdasarkan tahap-tahap pendekatan saintifik 5M (mengamati, menanya, menalar, mengasosiasi dan mengkomunikasikan), kemudian lebih diperinci dengan pemberian pertanyaan probing dan prompting kedalam masing-masing tahapan tersebut. Dengan demikian pembelajaran menggunakan modul yang sistematis dan terstruktur dapat dengan mudah diikuti siswa dalam mencapai tujuan pembelajaran. 
Perolehan rata-rata momen kappa modul pada komponen kegrafikan adalah sebesar 0,87 . Hal ini menunjukkan bahwa penampilan modul secara fisik telah baik, diantaranya jenis dan ukuran huruf yang digunakan jelas, gambar dan ilustrasi yang teramati, serta layout ataupun desain modul secara keseluruhan menarik. Sementara itu, tata letak yang baik akan menimbulkan daya tarik tersendiri terhadap minat belajar siswa [13]. Selain itu, ilustrasi yang jelas akan mempermudah siswa dalam memahami suatu konsep sehingga dapat mengurangi verbalisme dalam modul. Hal ini sesuai dengan penelitian terdahulu bahwa informasi verbal yang meaningless dapat dirubah menjadi lebih berarti, dalam penelitian ini berupa pertanyaan-pertanyaan yang menggali dan menuntun berdasarkan gambar/ ilustrasi yang diberikan [6].

Rata-rata momen kappa penilaian modul larutan elektrolit dan non elektrolit berbasis pendekatan saintifik dengan pertanyaan probing prompting pada uji validitas adalah sebesar 0,86 dengan kategori kevalidan sangat tinggi. Dengan demikian dapat disimpulkan bahwa modul yang dikembangkan telah valid.

3.3.2. Uji Praktikalitas. Terdapat 3 aspek penilaian untuk melihat kepraktisan suatu bahan ajar yang dikembangkan yaitu, kemudahan penggunaan, efisiensi waktu dan manfaat. Hasil analisis angket respon guru dan siswa pada penilaian aspek kemudahan penggunaan modul diperoleh kepraktisan yang sangat tinggi dengan rata-rata momen kappa sebesar 0,91 oleh guru dan 0,86 oleh siswa. Hal ini menunjukkan bahwa modul dapat digunakan dengan mudah bagi guru maupun siswa dari segi petunjuk penggunaan yang mudah dipahami, materi dan langkah-langkah kegiatan pembelajaran yang jelas, serta isi modul keseluruhan yang mudah dipahami. Dengan demikian penggunaan modul akan mendukung pembelajaran, dimana sebuah modul akan bermakna apabila siswa dapat dengan mudah menggunakannya [7].

Kepraktisan modul dari segi efisiensi waktu sangat tinggi baik penilaian oleh guru maupun siswa, dengan nilai rata-rata momen kappa sebesar 0,89 oleh guru dan 0,86 rata-rata penilaian oleh siswa. Hal ini menunjukkan bahwa waktu belajar menggunakan modul yang disediakan $8 \times 45$ menit efisien diterapkan dalam proses pembelajaran khususnya untuk materi pembelajaran larutan elektrolit dan non elektrolit. Dengan pembelajaran yang lebih efisien akan membantu siswa belajar sesuai dengan kecepatannya.

Dari segi manfaat, modul memiliki kepraktisan sangat tinggi berdasarkan penilaian angket oleh guru dengan rata-rata momen kappa sebesar 0,89. Begitu juga dengan penilaian angket praktikalitas oleh siswa diperoleh rata-rata momen kappa sebesar 0,89 dengan kepraktisan sangat tinggi. Nilai tersebut menunjukkan bahwa modul sangat bermanfaat dalam mendukung peran guru sebagai fasilitator serta membantu siswa memahami materi secara mandiri melalui pertanyaan-pertanyaan yang diberikan oleh guru. Hal tersebut dapat terwujud karena dengan adanya pertanyaan dapat merangsang motivasi dan ingin tahu siswa untuk belajar, dimana perhatian siswa akan lebih besar sehingga lebih mudah dalam memahami konsep [4].

Perolehan momen kappa masing-masing aspek penilaian praktikalitas modul dapat dilihat pada Grafik 2. Berdasarkan grafik tersebut dapat dilihat rata-rata momen kappa penilaian praktikalitas terhadap modul larutan elektrolit dan non elektrolit berbasis pendekatan saintifik dengan pertanyaan probing prompting, baik guru maupun siswa berada pada interval 0,81-1,00 dengan kategori kepraktisan sangat tinggi. Hasil analisis angket respon guru dan siswa diperoleh rata-rata momen kappa keseluruhan pada uji praktikalitas terhadap modul adalah 0,89 penilaian oleh guru dan 0,86 penilaian oleh siswa. Dengan demikian modul yang dikembangkan selain dinyatakan valid juga memiliki kepraktisan yang sangat tinggi. 


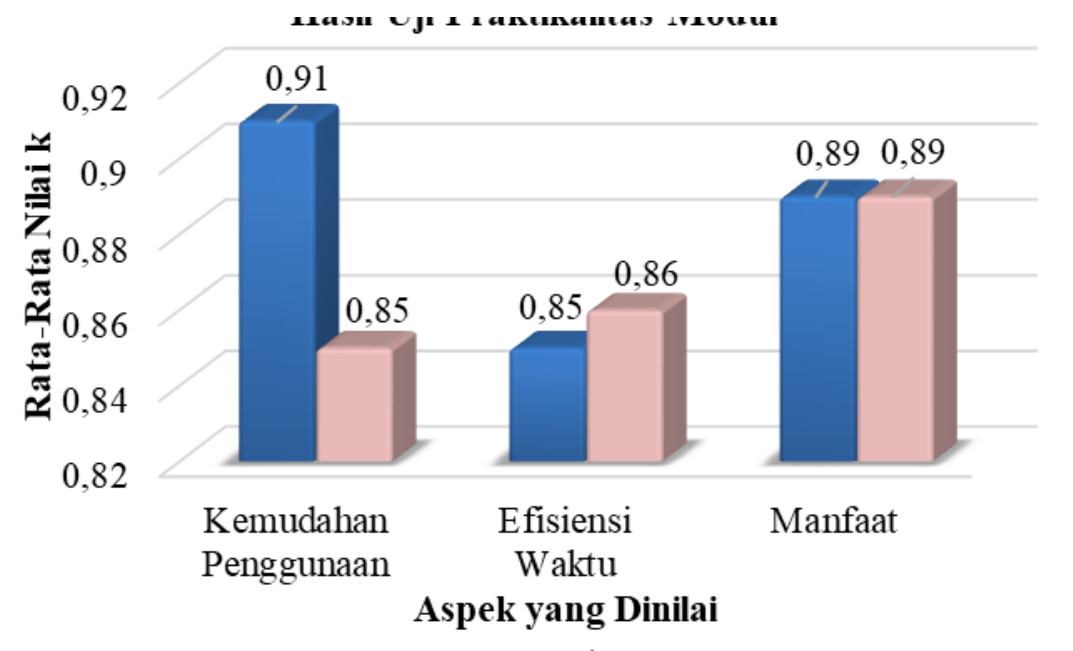

Grafik 2. Nilai momen kappa uji praktikalitas masing-masing komponen oleh guru dan siswa

\section{Kesimpulan}

Modul larutan elektrolit dan non elektrolit berbasis pendekatan saintifik dengan pertanyaan probing prompting untuk kelas X SMA/MA dapat dikembangkan melalui tahapan model pengembangan 4-D. Modul yang dikembangkan telah valid dan praktis dengan kategori kevalidan dan kepraktisan sangat tinggi.

\section{Referensi}

[1] Majid, A., \& Rochman, C. (2014). Pendekatan Ilmiah dalam Implementasi Kurikulum 2013. Bandung: PT Remaja Rosdakarya.

[2] Hosnan, M. (2014). Pendekatan Saintifik dan Kontekstual dalam Pembelajaran Abad 21. Bogor: Ghalia Indonesia.

[3] Kosasih, E. (2014). Strategi Belajar dan Pembelajaran Implementasi Kurikulum 2013. Bandung: CV. Pustaka Setia.

[4] Jalius, E. (2009). Pengembangan Program Pembelajaran. Padang: UNP Press.

[5] Suherman, E. (2003). Strategi Pembelajaran Matematika Kontemporer. Bandung: JICA UPI.

[6] Ellizar. 2015. Pengembangan Paket Pembelajaran Kimia dengan Aliran Konstruktivisme. Prosiding Semirata Bidang MIPA BKS-PTN Barat Universitas Tanjungpura. Hal: 640-649.

[7] Departemen Pendidikan Nasional. (2008). Panduan Pengembangan Bahan Ajar. Jakarta: Departemen Pendidikan Naional, Direktorat Jendral Manajemen Pendidikan Dasar dan Menengah, Direktorat Pembinaan Sekolah Menengah Atas.

[8] Ellizar. (2013). Pengaruh Motivasi dan Pembelajaran Kimia Menggunakan dan Tanpa Modul Terhadap Hasil Belajar Kimia di RSMA-BI. Prosiding Semirata FMIPA Universitas Lampung. Hal: 117-124.

[9] Utami, D. (2016). Penerapan Model Pembelajaran Probing Prompting dalam Pembelajaran Mengabstraksi Teks Negosiasi pada Siswa Kelas X SMA/MA, Jurnal Riksa Bahasa 2. Hal: 151-158.

[10] Jacobsen, D.A., Eggen, P., \& Kuchak, D. (2009). Method For Teaching. Yogyakarta: Pustaka Pelajar.

[11] Thiagarajan, S., Semmel, D.S., \& Semmel, M.I. (1974). Instructional Development for Training Teachers of Exceptional Children: A Sourcebook. Bloomington, Indiana: Indiana University.

[12] Sugiyono. (2012). Metode Penelitian Pendidikan, Pendekatan Kuantitatif, Kualitatif, dan R\&D. Bandung: Alfabeta.

[13] Hamdani. (2011). Strategi Belajar Mengajar. Bandung: CV Pustaka Setia. 